\title{
Article
}

\section{Cytokinin Perception in Ancient Plants beyond Angiospermae}

\author{
Sergey N. Lomin ${ }^{1}$, Ekaterina M. Savelieva ${ }^{1}$, Dmitry V. Arkhipov ${ }^{1}$, Pavel P. Pashkovskiy ${ }^{1}{ }^{1}$, \\ Yulia A. Myakushina ${ }^{1}$, Alexander Heyl ${ }^{2}$ (D) and Georgy A. Romanov ${ }^{1, *(D)}$ \\ 1 Timiryazev Institute of Plant Physiology, Russian Academy of Sciences, Botanicheskaya 35, \\ 127276 Moscow, Russia; losn1@yandex.ru (S.N.L.); savelievaek@ya.ru (E.M.S.); hotdogue@yandex.ru (D.V.A.); \\ pashkovskiy.pavel@gmail.com (P.P.P.); yulia-myakushina@yandex.ru (Y.A.M.) \\ 2 Biology Department, Adelphi University, Science 116, 1 South Avenue, Garden City, NY 11530-070, USA; \\ aheyl@adelphi.edu \\ * Correspondence: gar@ippras.ru or gromanov@yahoo.com
}

Citation: Lomin, S.N.; Savelieva, E.M.; Arkhipov, D.V.; Pashkovskiy, P.P.; Myakushina, Y.A.; Heyl, A.; Romanov, G.A. Cytokinin Perception in Ancient Plants beyond Angiospermae. Int. J. Mol. Sci. 2021, 22, 13077. https://doi.org/10.3390/ ijms222313077

Academic Editor: Karel Doležal

Received: 12 November 2021 Accepted: 30 November 2021 Published: 3 December 2021

Publisher's Note: MDPI stays neutral with regard to jurisdictional claims in published maps and institutional affiliations.

Copyright: (c) 2021 by the authors. Licensee MDPI, Basel, Switzerland. This article is an open access article distributed under the terms and conditions of the Creative Commons Attribution (CC BY) license (https:/ / creativecommons.org/licenses/by/ $4.0 /)$.

\begin{abstract}
Cytokinins (CKs) control many plant developmental processes and responses to environmental cues. Although the CK signaling is well understood, we are only beginning to decipher its evolution. Here, we investigated the CK perception apparatus in early-divergent plant species such as bryophyte Physcomitrium patens, lycophyte Selaginella moellendorffii, and gymnosperm Picea abies. Of the eight CHASE-domain containing histidine kinases (CHKs) examined, two CHKs, PpCHK3 and PpCHK4, did not bind CKs. All other $\mathrm{CHK}$ receptors showed high-affinity $\mathrm{CK}$ binding $\left(K_{\mathrm{D}}\right.$ of $\mathrm{nM}$ range), with a strong preference for isopentenyladenine over other $\mathrm{CK}$ nucleobases in the moss and for trans-zeatin over cis-zeatin in the gymnosperm. The $\mathrm{pH}$ dependences of $\mathrm{CK}$ binding for these six $\mathrm{CHKs}$ showed a wide range, which may indicate different subcellular localization of these receptors at either the plasma- or endoplasmic reticulum membrane. Thus, the properties of the whole CK perception apparatuses in early-divergent lineages were demonstrated. Data show that during land plant evolution there was a diversification of the ligand specificity of various CHKs, in particular, the rise in preference for trans-zeatin over cis-zeatin, which indicates a steadily increasing specialization of receptors to various CKs. Finally, this distinct preference of individual receptors to different CK versions culminated in vascular plants, especially angiosperms.
\end{abstract}

Keywords: cytokinin; receptor; signaling; plant evolution; binding affinity; ligand preference; $\mathrm{pH}$ dependence

\section{Introduction}

Hormonal regulation of biological processes is an integral part of the plant growth, development and adaptation to the environment. Due to massive genome sequencing, it has become possible to study the evolutionary formation of individual hormonal systems at the molecular level. Research has focused on the cytokinin (CK) hormonal system, with special attention on its hormone perception and signaling machinery. Apart from the model plant Arabidopsis [1-3], this machinery is already pretty well characterized in several representatives of angiosperms: Zea mays [4-7], Oryza sativa [8,9], Medicago truncatula [10,11], Brassica rapa [12], Malus domestica [13], Solanum tuberosum [14,15], Populus ssp $[16,17]$. However, data concerning species of other groups of higher plants, especially of phylogenetically most distant, are rather scarce [18-22].

In plants, an evolutionary advanced version of a two-component system (TCS) is responsible for the CK signaling. This system consists of a transmembrane (TM) receptor-a sensory hybrid histidine kinase $(\mathrm{HK})$, phosphotransmitters (HPts)—small mobile proteins, and response regulators (RRs) — which can be further subdivided into the RR-B, transcription factors, and the RR-A, negative regulators [3,23-26]. During signaling, a high-energy phosphate is transferred via conserved protein domains alternately along the histidine-aspartate-histidine-aspartate chain termed Multistep Phosphorelay (MSP), 
from the TM receptor via HPts to the nuclear type-B response regulator (RR-B). Receiving this phosphorylation signal, RR-Bs are activated and bind to promoters of the primary response genes, changing (mainly activating) their transcription. Among early proteins encoded by primary response genes, RRs type-A counteract the phosphorelay, creating the negative feedback loop in CK signaling. Arabidopsis has three CK receptors termed AHK2, AHK3 and (CRE1/)AHK4. Although they are capable of functionally replacing each other, they are not identical in their biochemical properties and physiological roles in the plant $[1-6,8,27-32]$.

Active natural CKs are currently assumed to be isoprenoid CKs-nucleobases [6,33]. There are several versions of such CKs: trans-zeatin (tZ), isopentenyladenine (iP), dihydrozeatin (DZ), and also cis-zeatin (cZ) in some plant species. Among Arabidopsis receptors, AHK3 has a high affinity for $\mathrm{tZ}$ and DZ at expense of iP, whereas AHK2 and AHK4 strongly bind $\mathrm{tZ}$ and $\mathrm{iP}$ but not DZ $[2,6,28,32]$. AHK4 is expressed predominantly in the root, while $A H K 2$ and $A H K 3$ in leaves [32,34,35]. In cereal plants, receptors are as different as their orthologs in Arabidopsis $[4,5,8]$.

CKs can move in a plant both along the xylem from root to shoot and along the phloem from shoot to root [36]. In this circuit, $\mathrm{tZ}$ riboside (tZR) predominantly moves upward along the xylem, and iP riboside (iPR) moves in both directions along the phloem [37]. Trans-zeatin is synthesized mainly in the root [38] and is essential for shoot growth [39] and transition to adult stage [40]. As for phloem-transported CKs, they have shown to regulate polar auxin transport and maintain vascular pattern in the root meristem [41]. A hypothesis was put forward about plant organ communication based on different forms of CKs, through receptors with different ligand specificity and different organ patterning, where orthologs of AHK2/AHK3 prevail, as a rule, in leaves, while AHK4-orthologs prevail in roots $[2,25,28,31,35,37]$. Thus, shoot-borne iP-type CKs obviously regulate the vital activity of the root via AHK4 orthologs, while root-borne tZ-type CKs regulate the vital activity of the shoot via AHK3/AHK2-orthologs [2,28,31].

Beyond flowering plants, CK signaling is studied very little. All land plants, in principle, have a complete set of proteins for the CK signal perception and transmission $[20,21,42]$, as described above. However, there are only a few studies describing the properties of CHK receptors in the bryophytes Physcomitrium (formerly Physcomitrella) patens (PpCHK1-4) and Marchantia polymorpha (MpCHK1) [19,21]. All known cytokinins (iP, tZ, cZ, DZ), their precursors and derivatives were found in the moss P. patens $[18,19,43]$. In addition, 6-benzyladenine (BA)-type aromatic CKs were detected. Furthermore, iP was found both outside and inside the cells, whereas tZ mainly inside; the outside-located iP exhibited high physiological activity in increasing bud number [18].

In Marchantia bryophyte, $\mathrm{cZ}$ was found to be the most abundant CK. Second and third positions are occupied by $\mathrm{tZ}$ (two-fold less) and iP (yet three-fold less), respectively [22].

Nothing is known about CKs in the lycophyte Selaginella moellendorffii, but in the closely related species Selaginella kraussiana, they suppressed dichotomous root branching caused by auxin [44], which may be a prototype for regulation of lateral root formation. In the fern Azolla filiculoides, CKs stimulated the growth of the root apical meristem, while auxins suppressed it [45], which is not typical for this hormone pair as compared to other plant groups.

As for gymnosperms, the bulk of studies of their hormonal systems has been carried out on conifers, where both iP- and Z-type CKs were found [46,47]. In the buds of Pinus radiata, active CKs-nucleobases, belonging to the group of isoprenoid $\mathrm{CKs}$, were detected. High- (tZ and iP) and low-activity (DZ and cZ) CKs were present in comparable amounts. No aromatic CKs have been reported [48]. Derivatives of these CKs in the form of ribosides, ribotides and glucosides have also been identified. When applied exogenously, BA was able to hydroxylate to meta-, ortho-, and para-topolins. Such native aromatic CKs were earlier detected in poplars $[49,50]$.

CKs are essential for conifers growing and propagating, they are used to regenerate these plants in in vitro culture $[51,52]$. The function of CKs in the secondary thickening 
of coniferous shoots is of great interest. Although in conifers auxin is considered leading hormone in shoot secondary growth $[53,54]$, CKs play an important role too by enhancing auxin effect $[55,56]$. CKs were detected in the wood and especially in the bark of Pinus sylvestris. In the latter, auxin-CK crosstalk was shown recently to be sufficient to determine the wood formation dynamics, where auxin controls cell enlargement rates while CKs drive cell division and auxin polar transport [57].

To our knowledge, no data on the biochemical properties of the CHK receptors from lycophytes or gymnosperms were reported so far. In our work, we tried to fill the gap in our knowledge on the CK perception apparatus of land plants, with special attention to early-divergent species (bryophytes, lycophytes and gymnosperms).

\section{Results}

\subsection{Ancient CHK Receptors in Comparative and Evolutionary Aspects}

$\mathrm{CHK}$ receptors typically consist of three basic modules. The $\mathrm{N}$-terminal extracytosolic sensory module is located on one side of the membrane, while catalytic and receiver modules are located in the cytosol, on the opposite side of the same membrane $[14,26,58,59]$. The sensory module contains the well-known CHASE domain (PF03924) [60,61] which is composed of PAS and PAS-like subdomains. The PAS subdomain is of special importance since it specifically binds the ligand that triggers the MSP. The adequate functioning of PAS subdomain is assured by highly conserved long pivotal $\alpha$-helix and short $\alpha$-helix located upstream and downstream of the CHASE domain, respectively [58]. The crystal structure of the sensory module of AHK4 became available since 2011 [33]. At present, CHASE domain is considered a hallmark of CHK receptors among various sensor HKs in plants [62]. Our analysis of genomes of non-flowering land plants: moss Physcomitrium patens, lycophyte Selaginella moellendorfii and spruce Picea abies, uncovered three, two and two typical CHASEcontaining HKs, respectively (Figure 1), in accordance with previous data [20,63]. To note, there is still an uncertainty with the receptor number in the lycophyte, in which four CHK-encoding genes were annotated in the GenBank, but they are so similar pairwise (termed as variants " $a$ " and " $b$ " here) (Figure S2) that they seem to represent sequencing repeats of two genuine $\mathrm{CHK}$ receptor genes.

Phylogenetically, $\mathrm{CHK}$ receptors were divided into a number of distinct clades (groups) (Figure 1A). Receptors of P. patens form a separate clade (Bryo, Bryophyta), the rest of CHKs form a common clade of vascular plants (VP) $[2,58,63]$. This common clade, in turn, is subdivided into the Lycophyta (Lyco) group with $S$. moellendorffii receptors and the seed plant group (SP). The latter group can be further divided into subgroups HK4 and HK2/3. The conifer receptors PaCHK1 and PaCHK2 belong just to these two subgroups, respectively.

Regarding the primary structure of receptor genes, some regularities can be traced (Figure 1B). In vascular plants, receptor CDS are usually composed of 11 exons. However, in some species there are deviations from this general rule. Spruce receptors have two additional small exons at the 3'end, whereas in SmCHK6a receptor of the lycophyte S. moellendorffii 2nd and 3rd exons are fused. In the moss P. patens, all three CHK receptor genes have a 14-exon structure. The superposition of gene exonic structures on encoded protein structures shows a fairly large similarity of the gene primary structures of all CHK receptors. Consequently, all plant CHK receptors share similar domain structure, and their sensory modules are flanked at both sides by TM helices (Figure 1C). These similar traits are evidence of the common origin of the $\mathrm{CHK}$ receptors. 
A

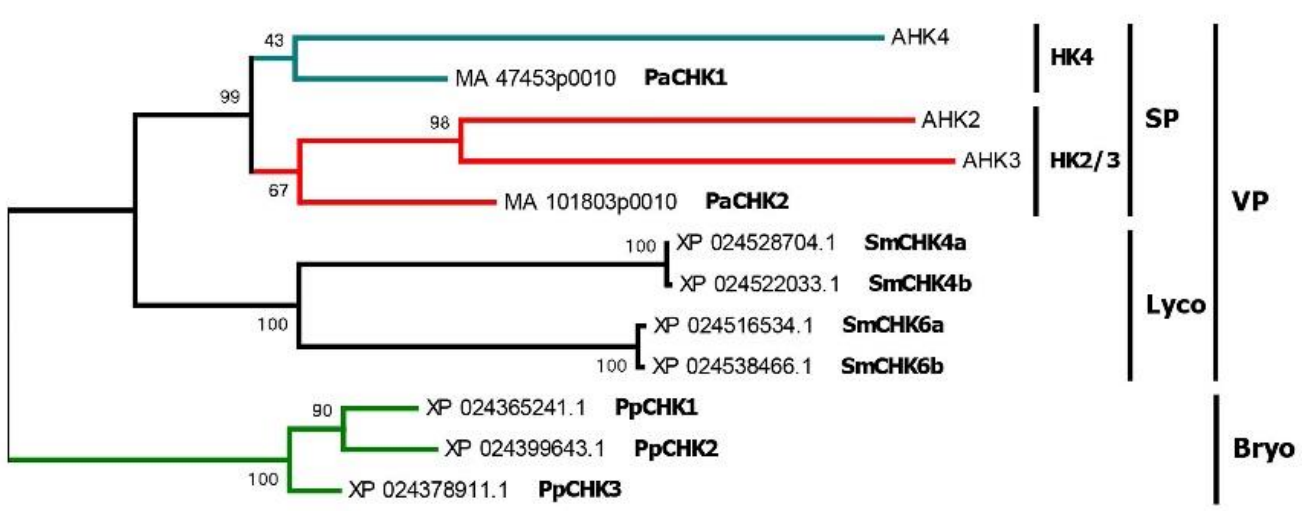

B $\longmapsto$

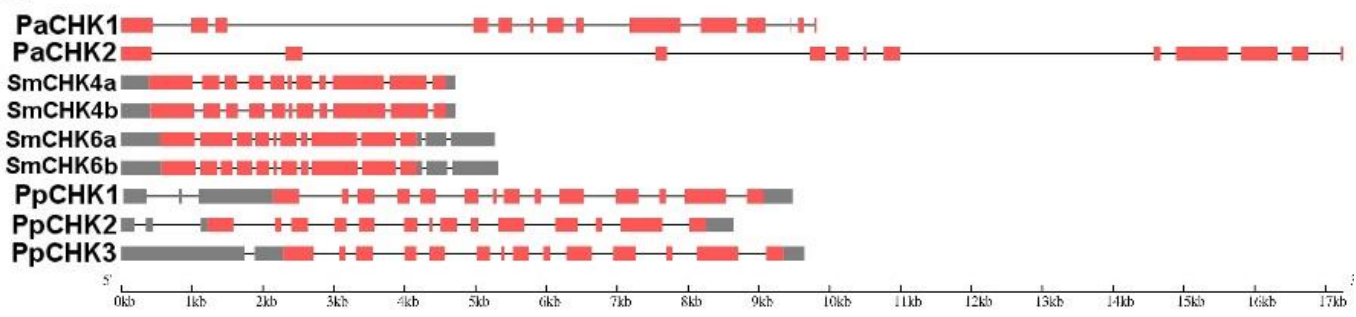

C
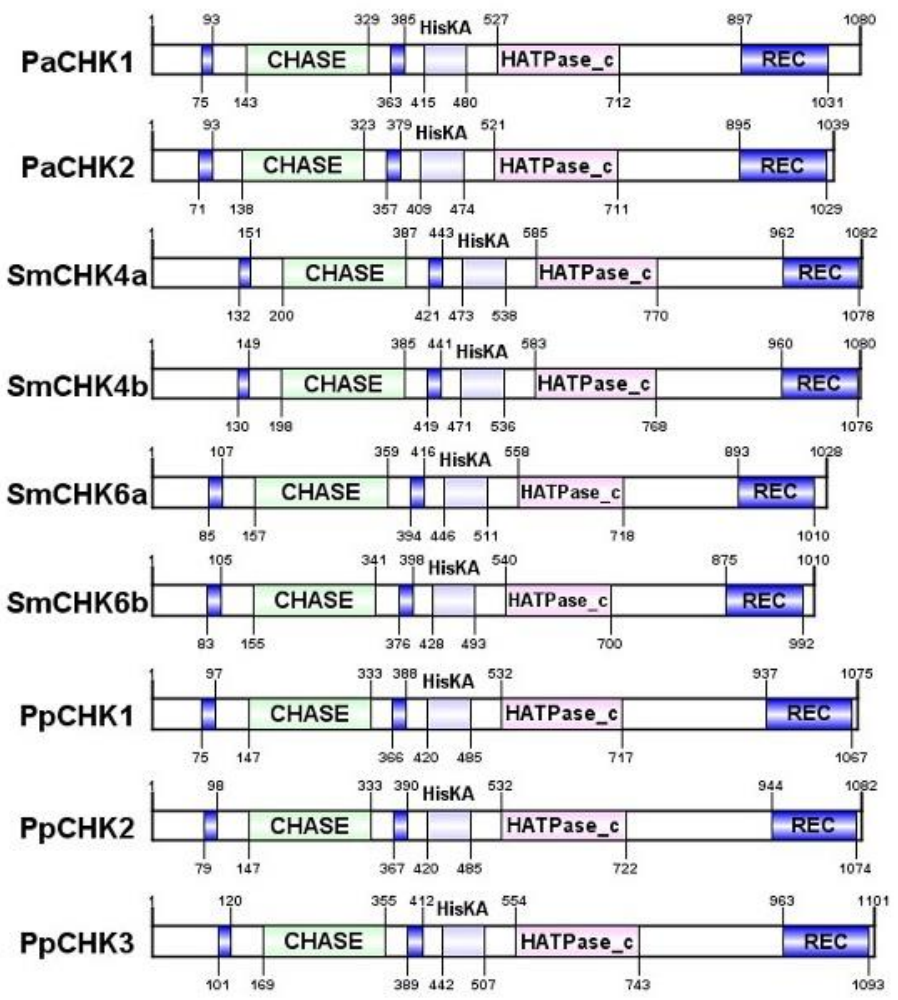

Figure 1. Bioinformatic analysis of the CHKs used in this study. (A) Molecular phylogenetic analysis by Maximum Likelihood method. VP-vascular plant, Bryo-Bryophyta, Lyco-Lycophyta, SP-Spermatophyta, HK4-Arabidopsis AHK4 clade, HK2/3-Arabidopsis AHK2 and AHK3 clades. (B) CHK gene structures. UTRs are marked gray, ORF are marked pink, bottom scale demonstrates gene length in kilobases. (C) CHK protein structures. CHASE domains are flanked by transmembrane domains colored in blue. Positions of domains termini and protein lengths are indicated in amino acid (aa) numbers. 
The moss P. patens was a unique species to have seven CHK receptor-related proteins, which we designated the sister CHK group (Figure S1). This subfamily was first discovered in phylogenetic studies of bryophytes P. patens and M. polymorpha [21]. Sister CHKs have severe abnormalities in the sensory module structure [64] (Figure S2). According to crystal structure of AHK4 sensory module [33], this module contains a number of amino acid (aa) residues critical for CK binding [2]. The long pivotal $\alpha$-helix occupies aa positions 283-327 of the general alignment. The right (distal) side of this $\alpha$-helix is usually very conserved in bona fide CK receptors, but in the sister group, many such positions are substituted by non-conserved residues. Moreover, there is a deletion at the beginning (aa positions 329-334) of the CHASE domain. Three substitutions are particularly noteworthy: Ala, Asp and Gly at positions 360, 434, and 493, respectively. Replacement of conserved Asp434 by different aa (Phe, Tyr, Leu) deserves special attention, since H-bond between Asp434 and adenine moiety of the $\mathrm{CK}$ is crucial for the hormone specific binding. In all sister CHKs the conserved Thr at position 450 is missing. In PpCHK6 this site is occupied by Trp, in other CHKs - by Ser. Thus, these CHKs may be considered versions of classical wol (wooden leg) mutation of Arabidopsis where CK binding is blocked. Collectively, all of the above suggests that sister CHKs bind CKs very weakly if at all. Hence, it is unlikely that these proteins can have a significant impact on CK perception.

On the other hand, to function as hybrid catalytic HKs, sister CHKs have everything they need, primarily HikA-, HATPase-c-, and REC-domains. The first domain (PF00512) contains an H-box with phosphorylatable His, the sequence of HATPase-cdomain (PF02518) includes N-, G1-, F, G2 and G3-boxes. The REC domain (PF00072) has a DD-box, a D1-box with phosphorylatable Asp, and a K-box. All of these consensus regions have a typical conserved structure in all considered proteins (Figure S2). Thus, they seem all to be functional hybrid HKs and their activity can be additive and/or supportive to the signal-transmitting activity of $\mathrm{CHK}$ receptors.

\subsection{Ligand Binding Properties of CHK Receptors from Early-Divergent Plants}

We experimentally analyzed the ligand-binding properties of $\mathrm{CHK}$ receptors from P. patens, S. moellendorffii, and P. abies using a radiolabeled ligand method and microsomes from tobacco leaves where these receptors were transiently expressed. Tritiated isopentenyladenine served as the labeled CK. PpCHK1 and 2 proteins from P. patens were tested in a full-length version, and otherwise sensory modules (SMs) flanked by TM helices were used. PpCHK1-3 represented canonical CHK receptor group, while PpCHK4 was a representative of the related sister group. From each pair of $S$. moellendorffii receptors, probably being two sequencing repeats, one representative (CHK4a-SM and CHK6-SM, in the last case CHK6-SM a and b are identical, so their specification by letter is unnecessary) was taken for further studies. The PaCHK1 and PaCHK2 pair of sensory HKs represents according to current knowledge the entire set of $\mathrm{CHK}$ receptors from P. abies.

Of the eight cloned receptors, we detected no CK binding for PpCHK3 and PpCHK4, although expression of these proteins was confirmed by immunoblotting against the fused GFP domain (Figure 2). The sensory module of the PpCHK3 protein (KJ697770) from P. patens, in comparison to the other canonical receptors considered in this work, seems to have on the whole rather conserved structure. The only marked aa substitution is Phe420 instead of conserved Ser. This substitution alone or in combination with others may be responsible for the current (Figure 2) and previous [19] data showing that PpCHK3 lacks the ability to bind labeled iP or $\mathrm{ZZ}$, respectively. Thus, from the initially selected eight CHKs, two (PpCHK3 and PpCHK4) were non-functional as the receptors since they did not recognize iP molecules. The remaining six $\mathrm{CHKs}$ strongly bound iP and possess typical structure of their sensory modules (Figure S3) indicating that they belong to the genuine CK receptors. 


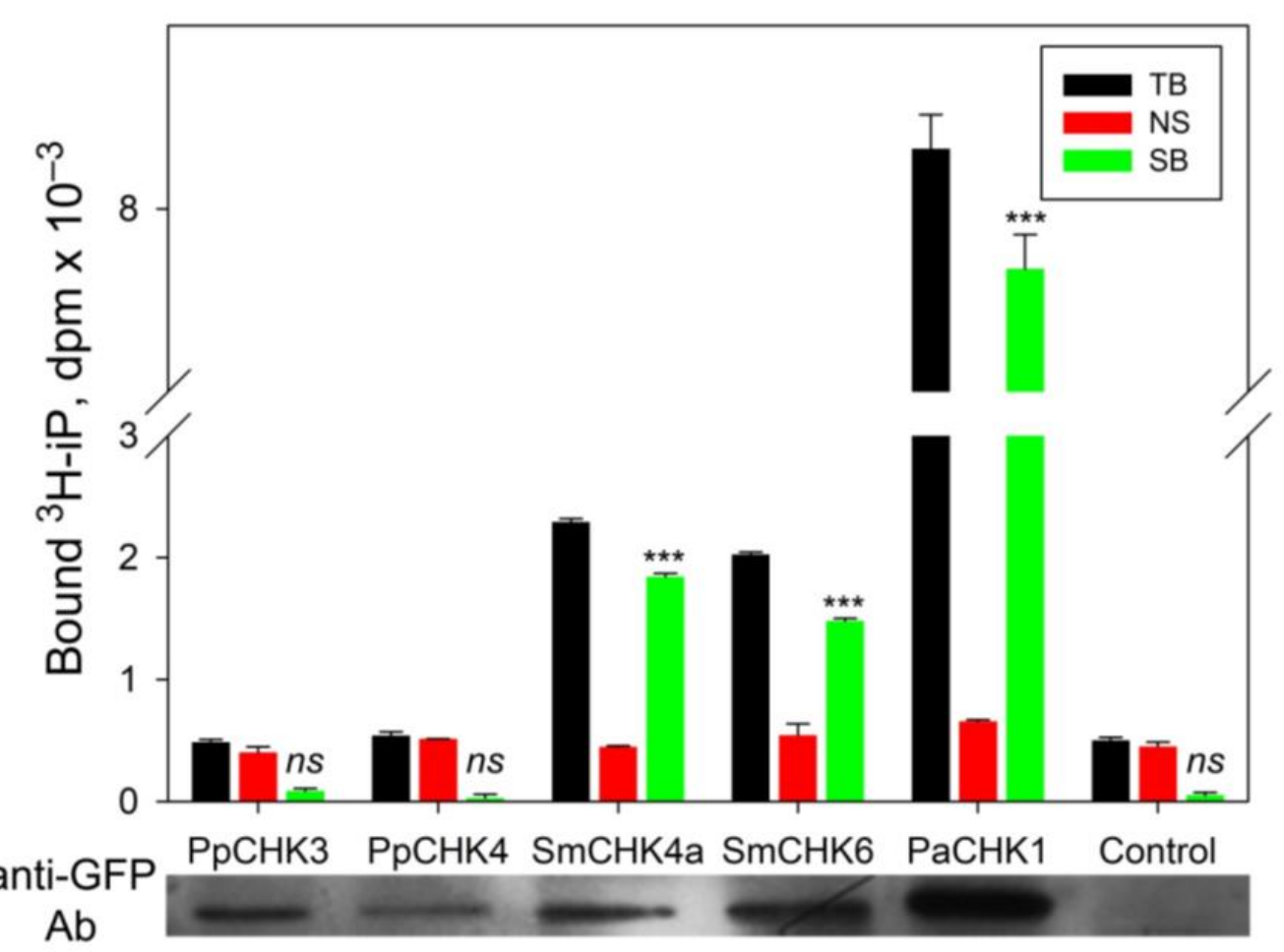

Figure 2. High affinity or lack of labeled iP binding by CHKs from moss Physcomitrium patens, lycophyte Selaginella moellendorffii and spruce Picea abies. For each case total (TB), non-specific (NS) and specific (SB) binding of ${ }^{3} \mathrm{H}$-iP was determined. Control probe shows the level of ${ }^{3} \mathrm{H}$-iP binding by endogenous CK receptors in tobacco leaves. Values for each receptor were validated using one-way ANOVA. Statistical significance of the difference between TB and NS is marked by stars (*** means $p$ value $\leq 0.001$, low case ns means not significant). At the bottom, Western blot with antibodies (Ab) against GFP protein fused to receptor moiety is shown, serving a proof for the receptor transient expression in tobacco leaves.

Then we conducted a detailed study on the $\mathrm{pH}$-dependence of the iP binding to receptors over a wide $\mathrm{pH}$ range (from $\mathrm{pH} 5$ to $\mathrm{pH}$ 9). All receptors showed a decrease in $\mathrm{CK}$ binding at $\mathrm{pH}$ below six. Meanwhile the PpCHK1, SmCHK6 and PaCHK1 receptors demonstrated an increase in binding from acidic to the highest alkaline values. In the case of SmCHK6, this increase was almost linear. PaCHK2 showed a similar, though less straight, growth trend. In contrast, PpCHK2 and SmCHK4a had clear binding maxima at $\mathrm{pH}$ 6-6.5 (Figure 3). In saturation experiments, the equilibrium dissociation constants $\left(K_{\mathrm{D}}\right)$ for iP were determined using the algorithm in the SigmaPlot program. $K_{\mathrm{D}}$ values ranged from 1.5 to $4.0 \mathrm{nM}$, which indicated a high affinity of this ligand to the studied CHK receptors (Figure 4).

The specificity of the receptors for six unlabeled hormones: trans-zeatin (tZ), cis-zeatin (cZ), isopentenyladenine (iP), dihydrozeatin (DZ), benzyladenine (BA), and thidiazuron (TD) - was determined in competition experiments. The dose-response curves of competitive CK binding are shown in Figure 5. Calculation of equilibrium $K_{D}$ was carried out by the standard method according to the Cheng-Prusoff formula [65]. The proposed alternative calculation algorithm produced similar results (see Appendix A and Table S2). 

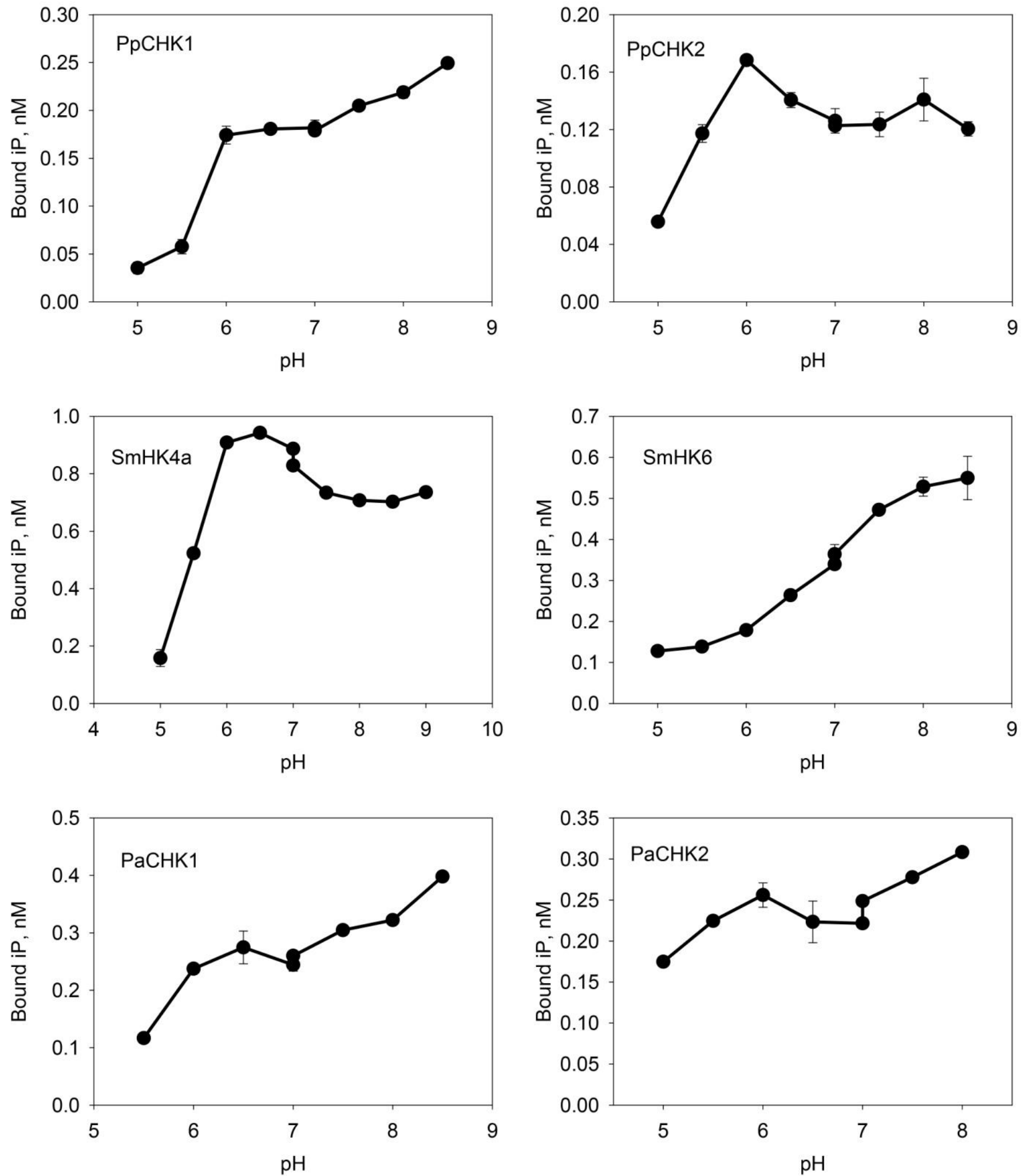

Figure 3. $\mathrm{pH}$-dependences of ${ }^{3} \mathrm{H}$-iP binding by $\mathrm{CHK}$ receptors from non-angiosperms: moss Physcomitrium patens, lycophyte Selaginella moellendorffii and spruce Picea abies. Graphics show specific binding (SB). Every curve demonstrates a decrease of CK binding at low $\mathrm{pH}$. 

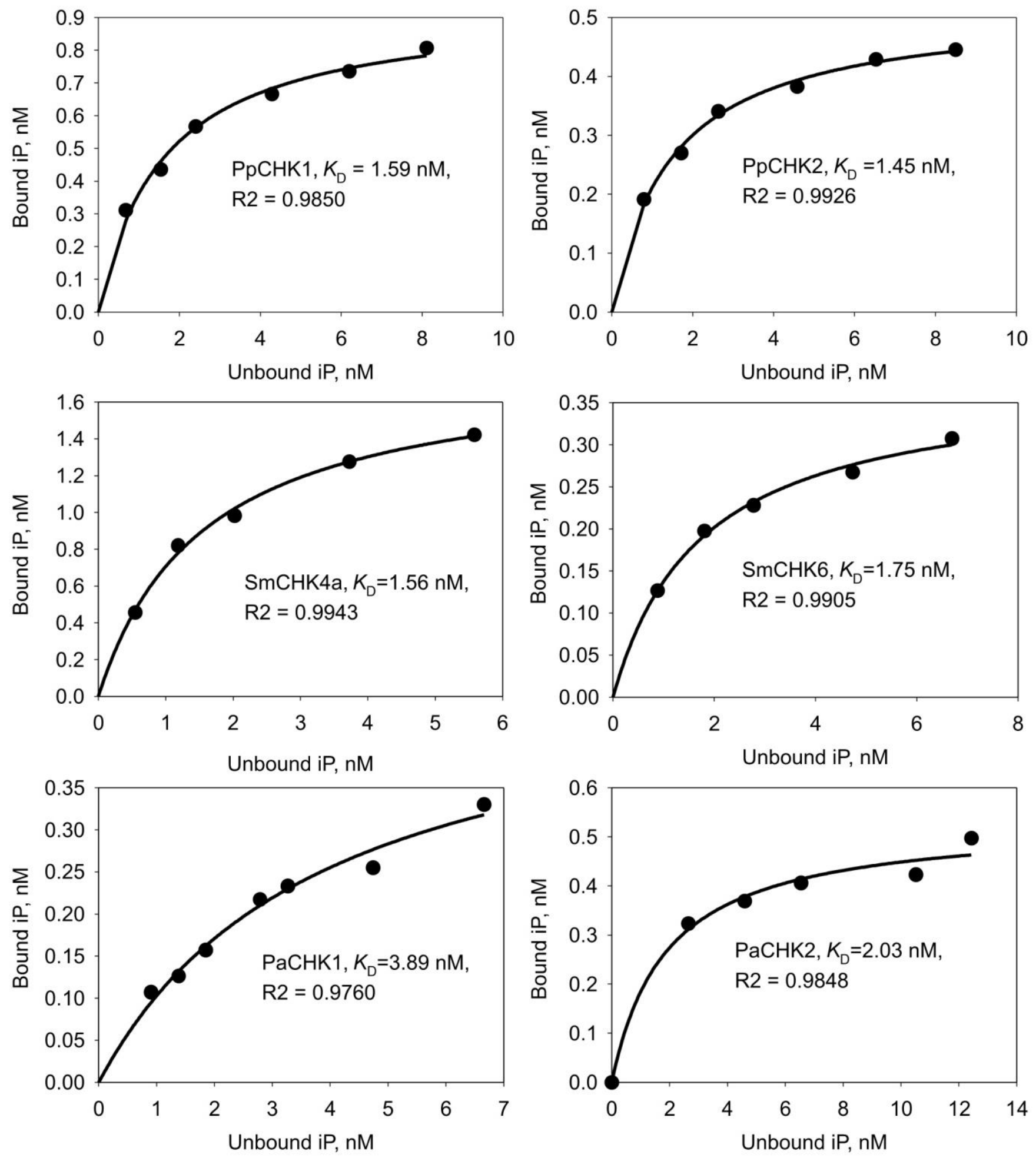

Figure 4. Saturation curves of ${ }^{3} \mathrm{H}-\mathrm{iP}$ binding to $\mathrm{CHK}$ receptors from non-angiosperms: moss Physcomitrium patens, lycophyte Selaginella moellendorffii and spruce Picea abies. Graphics show specific binding (SB). The goodness of fit for the non-linear regression model was estimated using the parameter R2 (see Section 4). The determined $K_{\mathrm{D}}$ values are very close and fall into narrow range of 1-4 nM, typical for high-affinity hormone-receptor binding. 


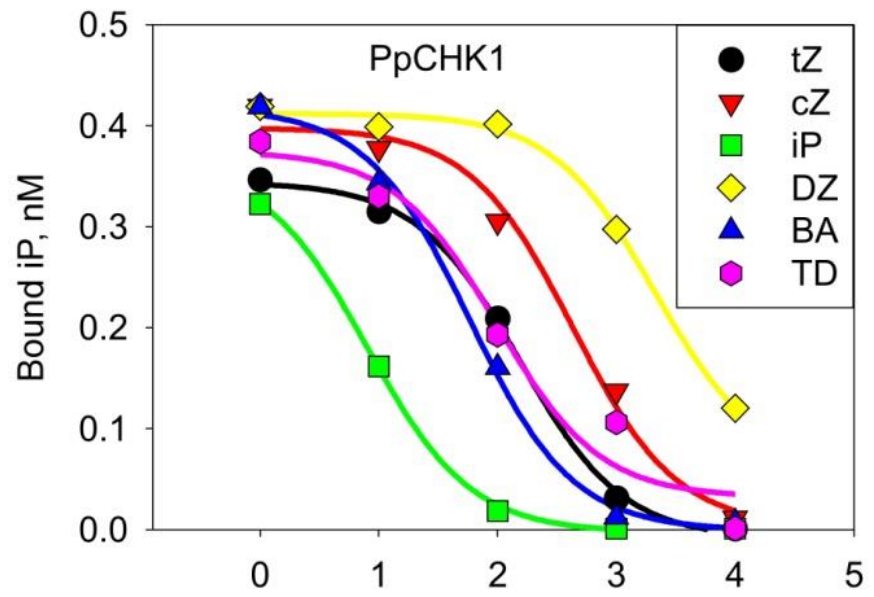

Concentration of unlabeled ligand, $\mathrm{Lg}(\mathrm{nM})$

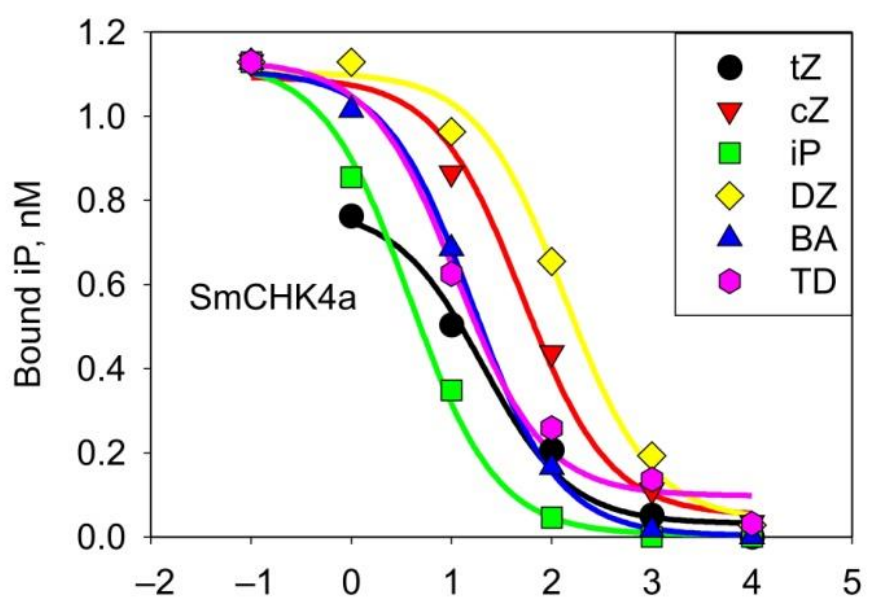

Concentration of unlabeled ligand, $\mathrm{Lg}(\mathrm{nM})$

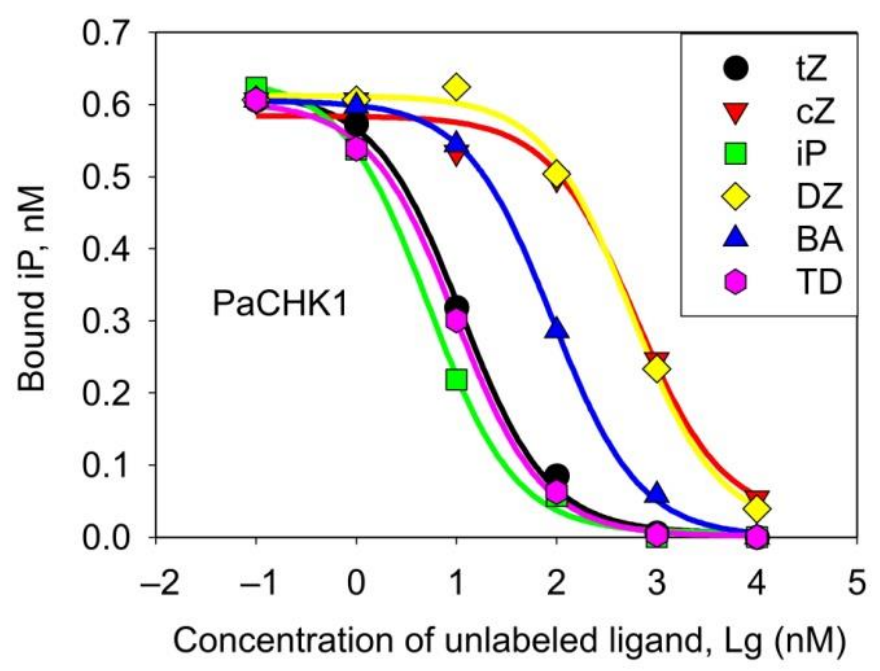

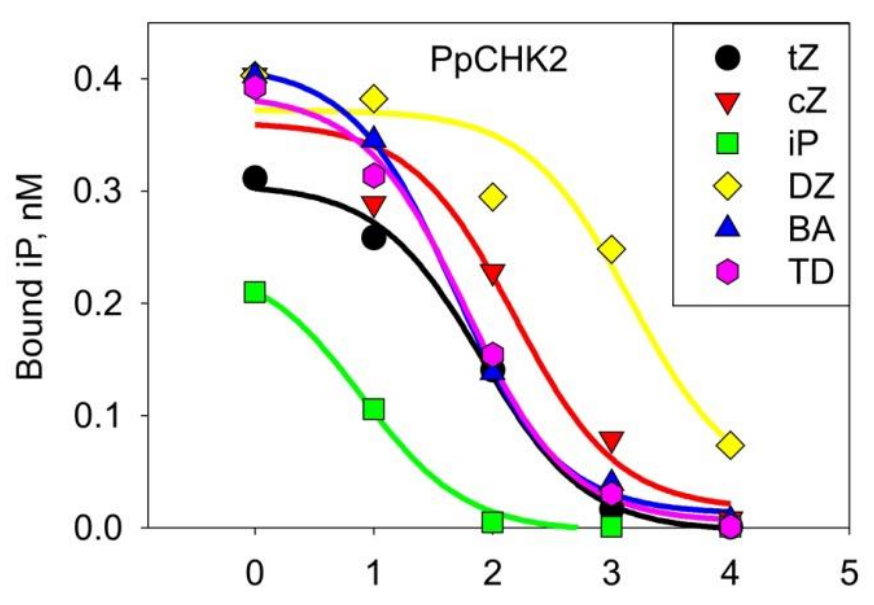

Concentration of unlabeled ligand, $\mathrm{Lg}(\mathrm{nM})$

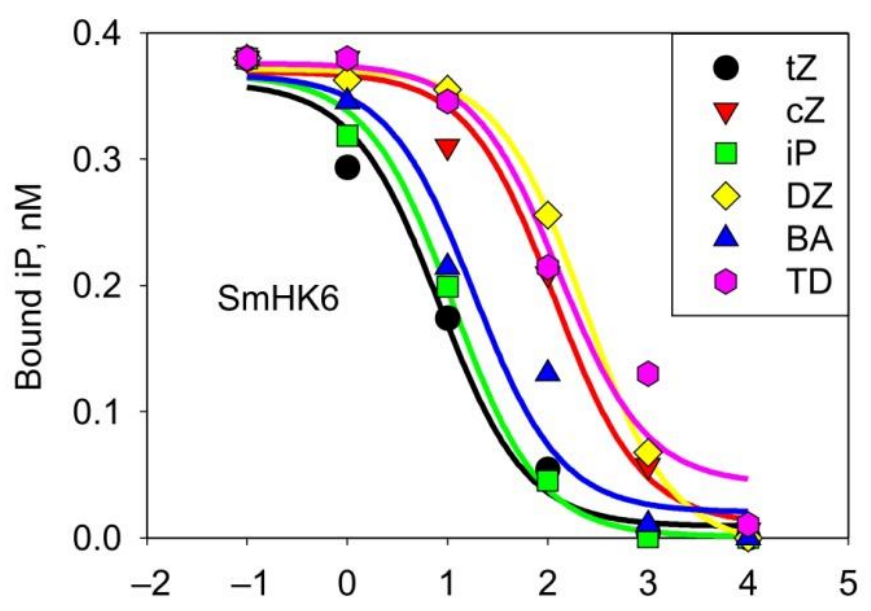

Concentration of unlabeled ligand, $\operatorname{Lg}(\mathrm{nM})$

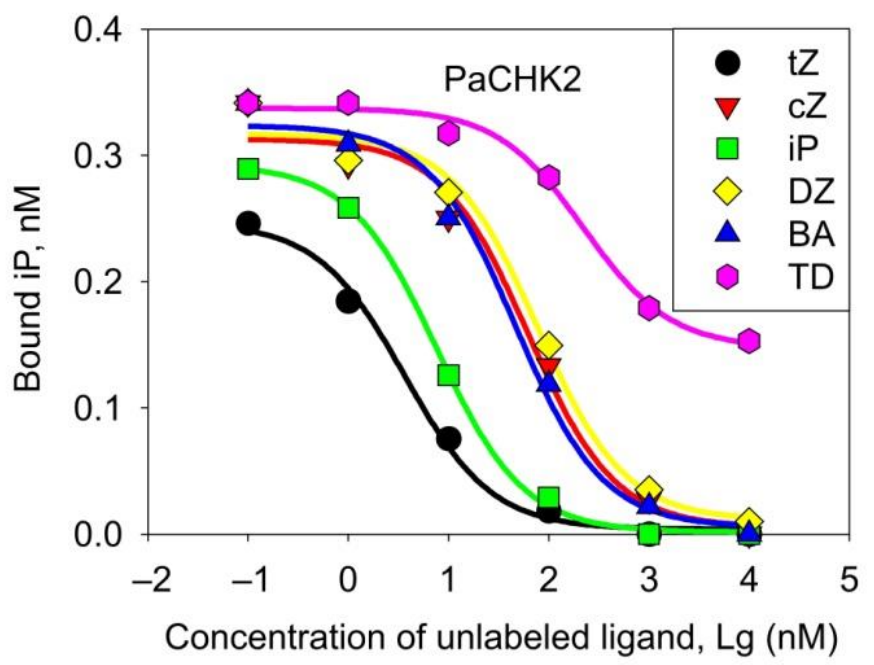

Figure 5. Competition curves of ${ }^{3} \mathrm{H}$-iP displacement by unlabeled $\mathrm{CK}$ s from the binding sites in $\mathrm{CHK}$ receptors originating from non-angiosperms. $\mathrm{tZ}$, trans-zeatin; $\mathrm{cZ}$, cis-zeatin; iP, isopentenyladenine; DZ, dihydrozeatin; BA, 6-benzyladenine; TD, thidiazuron.

The affinity data of various CKs to cognate receptors are shown in Table 1 . The P. patens receptors exhibited the highest affinity $\left(K_{\mathrm{D}}<10 \mathrm{nM}\right)$ for iP. According to $K_{\mathrm{D}}$ 
calculation, affinity for $\mathrm{tZ}$ was much lower, while $\mathrm{cZ}$ and DZ rounded out the list. In contrast, vascular plant receptors, apart from iP, strongly bound also $t Z$ and BA, but not $\mathrm{cZ}$ or DZ. Selaginella receptors were distinguished by relatively high affinity towards BA. In addition, SmCHK4a and PaCHK1 strongly bound thidiazuron (TD), a synthetic phenylurea-derived CK. SmCHK6 bound iP and $t Z$ with the close affinities, SmCHK4a and $P a C H K 1$ preferred $i P$, while PaCHK2 preferred $t Z$. The highest variation ranges between two $\mathrm{CHK}$ receptors of the same species was a feature of spruce receptors. For example, the PaCHK1/CHK2 affinity ratios $\left(K_{\mathrm{D} 1} / K_{\mathrm{D} 2}\right)$ for $\mathrm{tZ}, \mathrm{cZ}, \mathrm{DZ}$ and TD were $7.21,23.4,16.8$ and 0.1 , respectively. For comparison, the corresponding values of PpCHK1/CHK2 affinity ratios for the same CKs: 2.04, 3.01, 1.37 and 1.83, respectively, indicated much less variations in the moss. The maximal to minimal affinity ratio for spruce receptors was equal to quotient of division $23.4 / 0.1=234$; the analogous value for moss receptors was only 3.01/1.08 $=2.8$. CHK receptors of lycophyte, phylogenetically positioned somewhere between moss and spruce, have an intermediate value of this parameter: 25.7, which is almost an order of magnitude higher than that of $P$. patens, but almost an order of magnitude lower than that of P. abies. Both CK receptors from moss hardly distinguished between cis- and trans-Zeatins, $K_{\mathrm{D}}$ 's for these two CKs for both PpCHK1 and PpCHK2 were very close (Table 1), with the $\mathrm{cZ} / \mathrm{tZ} K_{\mathrm{D}}$ ratios being 2.79 and 1.89 , respectively. In the lycophyte, at least one CK-receptor already became much more specific. Although SmCHK4a still had a fairly close affinities for $c Z$ and $t Z\left(K_{D}\right.$ ratio 2.58), SmCHK6 recognized $t Z$ much better than $c Z\left(K_{D}\right.$ ratio 10.09). A further enhancement of specificity was detected in spruce $\mathrm{CHK}$ receptors: $\mathrm{cZ} / \mathrm{tZ} K_{\mathrm{D}}$ ratio for PaCHK1 and PaCHK2 was 55.4 and 17.0, respectively. Thus, during the transition from bryophytes to seed plants, there was a clear development of the receptor preference towards distinct $\mathrm{CK}$ versions.

Table 1. Quantitation of the affinities of CHK receptors from early-divergent lineages for all essential CK versions (ChengPrusoff calculation method).

\begin{tabular}{|c|c|c|c|c|c|c|}
\hline \multirow{2}{*}{ CK Version } & \multicolumn{6}{|c|}{$K_{\mathrm{D}}$ of CK-Receptor Complexes (nM $\pm \mathrm{SE}$ ) for: } \\
\hline & PpCHK1 & РpCHK2 & SmCHK4a & SmCHK6 & PaCHK1 & PaCHK2 \\
\hline $\mathrm{t} Z$ & $36.9 \pm 2$ & $18.1 \pm 1.5$ & $7.99 \pm 1.34$ & $1.15 \pm 0.20$ & $7.57 \pm 0.37$ & $1.05 \pm 0.09$ \\
\hline $\mathrm{cZ}$ & $103 \pm 15$ & $34.2 \pm 9.3$ & $20.6 \pm 2.6$ & $16.6 \pm 2.4$ & $419 \pm 56$ & $17.9 \pm 2.9$ \\
\hline iP & $1.92 \pm 0.06$ & $1.78 \pm 0.14$ & $1.60 \pm 0.13$ & $1.70 \pm 0.16$ & $3.60 \pm 0.17$ & $2.20 \pm 0.08$ \\
\hline DZ & $507 \pm 42$ & $323 \pm 97$ & $54.8 \pm 6.2$ & $36.0 \pm 1.6$ & $377 \pm 27$ & $22.4 \pm 2.9$ \\
\hline BA & $13.9 \pm 0.1$ & $10.7 \pm 0.5$ & $6.91 \pm 0.34$ & $2.28 \pm 0.70$ & $61.9 \pm 1.3$ & $13.5 \pm 1.6$ \\
\hline TD & $23.8 \pm 5.4$ & $13.02 \pm 0.2$ & $4.52 \pm 0.62$ & $16.6 \pm 4.7$ & $6.70 \pm 0.21$ & $64.5 \pm 6.4$ \\
\hline
\end{tabular}

Values less than $10 \mathrm{nM}$ (attesting for high affinity) are highlighted in bold. Abbreviations: Pp, Physcomitrium patens; Sm, Selaginella moellendorffii; $\mathrm{Pa}$, Picea abies.

\section{Discussion}

In the work presented here, we studied the main biochemical features of CHK receptors from plants with sequenced genomes belonging to three key groups of land plant evolution [63,66]. These are representatives of bryophytes Physcomitrium patens, lycophytes Selaginella moellendorffii, and gymnosperms Picea abies. The earliest time of their appearance in evolution is estimated as 506.4, 432.5 and $302.8 \mathrm{Ma}$, respectively (compare with time of Angiospermae appearance-246.6 Ma) [67]. Thus, the selected species are important milestones in the land plant evolution.

\subsection{Lessons from Experimental Studies of CHK Receptors from Early-Divergent Lineages \\ 3.1.1. Selection of Representative Receptors}

We investigated the hormone-binding properties of eight putative $\mathrm{CHK}$ receptors from three early-divergent plant species. The receptors of lycophytes and gymnosperms have been studied for the first time at the protein level. Among sensor HKs, PpCHK1 and PpCHK2 of $P$. patens displayed typical properties of CHK receptors, whereas PpCHK3 from the main receptor group and PpCHK4 from a distinct $\mathrm{CHK}$ clade termed sister group did 
not bind $\mathrm{CK}$ with receptor-befitting affinity. It was previously noted that PpCHK3 did not bind labeled $t Z$ and that plants with knocked-out $P p C H K 1-3$ genes stop responding to CK despite the presence of intact genes from the sister group [19]. Our bioinformatic analysis indicated some putative structural reasons for the inability of PpCHK3 and PpCHK4 to bind CKs. All these data cast strong doubt on the real involvement of PpCHK3 and sister $\mathrm{CHKs}$ in the perception of the CK signal. These two P. patens HKs, which were unable to specifically bind CK, were excluded from further studies. In S. moellendorffii, the available four receptor genes are very similar pairwise to each other likely being sequencing repeats of two genuine receptor genes, so we investigated the properties of one receptor of each pair. The ligand-binding properties of both spruce receptors, which we named PaCHK1 and $\mathrm{PaCHK} 2$, were also studied in-depth. Thus, for the first time, the ligand-binding properties of the CK perception apparatus of several early-divergent plant species, unique from evolutionary viewpoint, have been experimentally investigated.

\subsubsection{The $\mathrm{pH}$ Dependence of Ligand Binding}

According to presented data, most of the receptors of ancient plants have a typical $\mathrm{pH}$ dependence of CK binding, with a decrease at the acidic region, which indicates a preferred intracellular localization. The exceptions were the moss receptor PpCHK2 and the spruce receptor $\mathrm{PaCHK} 2$, which retained a sufficiently high ligand-binding activity at $\mathrm{pH} 5.5$ and even $\mathrm{pH} 5.0$ (PaCHK2). This shows the ability of these receptors to function also within the plasma membrane in an apoplastic environment, for which the $\mathrm{pH}$ range 4.5-5.5 is typical [68]. Since the main CK in the moss, iP, acts extracellularly [18], it is very likely that it acts principally on the PpCHK2 receptor which resides tentatively in the plasma membrane. Thus, it may be suggested that competent protonema cells-progenitors of bud formation-actively express the $P p C H K 2$ gene, to be ready to recognize the apparition of extracellular iP, the inducer of bud differentiation.

In turn, the potential localization of most of the $\mathrm{CHK}$ receptors inside the cell opens up for them the possibility to perform some basic functions aimed at preserving the intracellular homeostasis. In particular, among putative functions, that of $\mathrm{pH}$ sensing seems to be one of most plausible for some reasons. This is especially true for those receptors which are characterized by a monotonic increase in CK binding with increasing $\mathrm{pH}$. Such a quasi-linear $\mathrm{pH}$ dependence was observed for receptors from lycophyte SmCHK6, gymnosperms PaCHK1 (Figure 3), as well as from flowering plants: maize ZmHK1 [6], and potato StHK4b [14]. Another reason is the close structural similarity of CHK receptors to bacterial $\mathrm{pH}$ sensors. For instance, such a classical $\mathrm{pH}$ sensor of bacteria as the chemoreceptor TlpB from Helicobacter pylori is a typical TCS HK that perceives a signal, i.e., the level of intracellular $\mathrm{pH}$, in the process of ligand (urea) binding in PAS domain of its sensory module [69]. This is direct analogy with HKs-CHK receptors, which bind their ligands, including urea derivatives, also in the PAS (sub)domain of the sensory module, and in both cases the conserved Asp in the binding site plays the key role in ligand recognition [6].

In the moss $P$. patens, the $\mathrm{PpCHK} 1$ receptor exhibits a $\mathrm{pH}$ dependence that also resembles a quasi-linear one with increasing ligand binding to the highest $\mathrm{pH}$ values (9); this relationship is very different from the $\mathrm{pH}$ dependence of another moss receptor, PpCHK2. Therefore, we can assume that the PpCHK1 receptor, which is seemingly located inside the cell, acts also as a $\mathrm{pH}$ sensor, maintaining a steady state (neutral—weakly basic $\mathrm{pH}$ ) of the internal milieu in the cells. Most likely, the CHK receptors are not the only or even the main $\mathrm{pH}$ sensors that monitor this parameter of plant cells, but rather act as part of a complex pH-control system.

\subsubsection{Ligand Specificity of CHK Receptors}

In binding assays, $K_{\mathrm{D}}$ 's of complexes iP-receptors were in the range of $1.5-4.0 \mathrm{nM}$, which is typical for hormonal receptors in general and CK receptors in particular. The ligand specificity of the receptors was determined in competition experiments. Of all tested CKs, P. patens receptors had a clear preference for iP. Receptors of later diverging 
(or modern) land plants increase their affinity for $\mathrm{t} Z$, but retain high iP binding affinity as well. While one of the two pairs of receptors (SmCHK6) in the lycophyte has high and close affinities for $\mathrm{iP}$ and $\mathrm{tZ}$, one of the two spruce receptors PaCHK2 binds $\mathrm{tZ}$ significantly stronger than iP. Clear changes in the receptor affinity for other ligands were also revealed. For example, the receptors from Selaginella (SmCHKs) showed a high affinity for BA, and receptors from spruce (PaCHK1) and again Selaginella SmCHK4a- a high affinity for TD. The increase in the specificity of receptors in relation to structurally similar $\mathrm{cZ}$ and $\mathrm{tZ}$ in the course of plant evolution is particularly indicative. Although both receptors in the moss prefer $\mathrm{tZ}$ over $\mathrm{cZ}$, the difference in affinity for cis- and trans-zeatin was rather small. In the lycophyte, one of the two receptors (SmCHK6) sharply increased the affinity for $t Z$, while the affinity for $\mathrm{CZ}$ remained low. As regards the spruce receptors, the differentiation between cis- and trans-zeatin was further enhanced, primarily due to a decrease in the affinity for $\mathrm{cZ}$ in PaCHK1. It is worth mentioning that the specialization of receptors with respect to cis- and trans-zeatin did not stop there, but continued in flowering plants in the same direction, albeit in a receptor-specific manner. An example among Angiospermae CK receptors is AHK3 from A. thaliana, whose affinity for $\mathrm{tZ}$ exceeds that for $\mathrm{cZ}\left(\mathrm{cZ} / \mathrm{tZ} K_{\mathrm{D}}\right.$ ratio) by 376-folds [6]. At the same time, there are CK receptors, for example, the ZmHK1 of maize, which retains archaic features, in particular, an almost equal affinity for cis- and trans-zeatin. Such a sharp differentiation of CK receptors in the ligand specificity indicates further specialization of their functions in plants.

\subsection{Non-CK-Binding CHKs Can Participate in CK Signaling}

Despite the common origin of the moss $\mathrm{CHK}$ receptors and CHKs of the sister group (Figure S1), the cellular function of the latter remains obscure. The inability of these proteins to bind CK with high affinity seemingly precludes their participation in CK signaling. However, this blocking relates to CK perception, but not signal transduction stage. The reason for that is the experimentally proven capacity of $\mathrm{CK}$ receptors to form heterodimers in vitro [70] and in planta [59,71]. In such heterodimers, one CK sensing moiety can be sufficient to recognize the hormone and trigger the signaling process. Furthermore, apart from CK perception, $\mathrm{PpCHKs}$ of the sister group evidently have all the functional domains and some have been shown to possess all activities necessary to transduce CK signal up to phosphotransfer proteins [21]. Thus, PpCHKs of the sister group in P. patens can play some supporting role as a factor which supplements and enhances the CK signal transduction. The same rational explanation can be true also for the bryophyte PpCHK3 protein which evidently lost its CK binding ability but nevertheless can take part in CK signaling in planta [19]. Generally, the activity of various functional HKs may supplement and/or simulate the activity of CHK receptors regardless the presence of CKs. Therefore, to consider the relevant CK-triggered downstream MSP (Multistep Phosphorelay) signaling, it is necessary to take into account the possible participation in the process not only bona fide $\mathrm{CHK}$ receptors, but also other hybrid HKs.

\subsection{Probable Scenario for the Evolution of the CK System}

It is conceivable that the essential CK functions in early-divergent lineages were restricted to control some basic cellular parameters such as intracellular $\mathrm{pH}$ and/or (in mosses) induction of bud formation on the protonema. In contrast with the vast majority of other plant species, P. patens has neither homologs of $I P T$ genes for direct CK synthesis, nor homologs of cytochrome P CYP735A genes which encode enzymes producing tZ-type CKs from iP-type. Therefore, it seems natural that iP, released upon the decomposition of prenylated tRNA, is sufficient in the moss for these simple physiological purposes. Accordingly, moss receptors strongly prefer iP over other widespread CKs. It is noteworthy that the two functional CK receptors in the moss differ not so much in ligand specificity as in $\mathrm{pH}$ dependence of ligand binding. It is possible that the latter difference is due to their distinct subcellular localization: one of the receptors is likely located on the plasma membrane and stimulates the bud formation, while the other resides tentatively in the 
endoplasmic reticulum and maintains somehow the physiological status of the cell (for example, by controlling the intracellular $\mathrm{pH}$ ). Obviously, during land plant evolution, the number of CK functions has been constantly increasing, so in vascular plants their role has become much more versatile and important [26].

Thus, in the course of evolution, the CK signaling system gained great importance and multifunctionality, which caused its perfecting and rapid development towards the virtual monopolization of MSP; direct, not through tRNA, CK synthesis, as well as expansion of the receptor specificity with their subsequent specialization to certain CKs in flowering plants. At the same time, the CK system acquired greater reliability, stability and plasticity, as evidences, in particular, its resistance against blocking (knockouting) of one or another of its essential elements $[31,72]$ as well as fine-tune coordination of the CK system with other hormonal systems, primarily auxin [73,74] and ethylene [75] ones, to ensure the optimal development of the plant organism.

\section{Materials and Methods}

\subsection{Bioinformatics Methods}

The protein sequences of Arabidopsis cytokinin receptors were used to search for the corresponding genes in other plant species. For this purpose, online services of protein BLAST in the corresponding databases were used. Genes of Oryza sativa, Amborella tricopoda, Selaginella moellendorffii, Physcomitrium patens were found in the NCBI database (https:/ / www.ncbi.nlm.nih.gov/, accessed on 10 September 2021); Picea abies-in ConGenIE.org (https: / / congenie.org, accessed on 10 September 2021); Ginkgo biloba-in Medicinal Plant Genomics Resource (http:/ / mpgr.uga.edu/, accessed on 14 May 2021); Azolla filiculoides-in Fernbase (https://www.fernbase.org/, accessed on 21 September 2021); Gnetum montanum and Anthoceros agrestis, in The 1000 plant transcriptomes initiative (1KP) (https:// db.cngb.org/onekp/, accessed on 24 September 2021); Marchantia polymorpha-in Phytozome 13 (https:/ / phytozome-next.jgi.doe.gov/, accessed on 24 September 2021).

For the functional domain search, a number of various online services were used HMMER (https:/ / www.ebi.ac.uk/Tools/hmmer/search/hmmscan, accessed on 24 September 2021) PROSITE (https:/ / prosite.expasy.org/scanprosite/, accessed on 24 September 2021), SMART (http:/ / smart.embl-heidelberg.de/, accessed on 24 September 2021). The TMHMM2 program on the DTU Health Tech Web site (https://services.healthtech.dtu. dk/service.php?TMHMM-2.0, accessed on 24 September 2021) was additionally used for TM domain search. Functional protein sequences were verified by the alignment using ClustalW algorithm in MEGA11 [76,77]. The evolutionary history was inferred by using the Maximum Likelihood method based on the Equal Input model [78]. The tree with the highest log likelihood is shown. The percentage of trees in which the associated taxa clustered together is shown next to the branches. Initial tree(s) for the heuristic search were obtained by applying the Neighbor-Joining method to a matrix of pairwise distances estimated using a JTT model. A discrete Gamma distribution was used to model evolutionary rate differences among sites ( 2 categories $(+G$, parameter $=0.5877)$ ). The tree is drawn to scale, with branch lengths measured in the number of substitutions per site. The analysis involved 12 amino acid sequences. There were a total of 1355 positions in the final dataset. Evolutionary analyses were conducted in MEGA11. The parameters for phylogenetic tree construction are given in the legend to Figure S1. Pictures of gene structures were drawn by Gene Structure Display Server (http:/ /gsds.cbi.pku.edu.cn/, accessed on 11 March 2021) [79]. Structures of proteins with domains were drawn by Illustrator for Biological Sequences (IBS 1.0).

The molecular modeling of 3D CHK receptor structures was run out in Modeller 9.19 software [80], using automodel class for comparative modeling. For each structure 200 models were built, and the best one was chosen according to the DOPE score [81]. The crystal structure of AHK4 receptor (PDB ID: 3T4L) [33] was employed as a template for modeling. Additional structure prediction was performed using IntFOLD Server (Version 6.0) [82]. Models were energy minimized in UCSF Chimera 1.14 [83] using 
an AMBER 14SB force field [84] with 300 steps of steepest descent and 300 steps of conjugate gradient.

\subsection{RNA Isolation from Picea abies Fir-Needles}

RNA isolation was performed according to the method of [85] with some modifications [86]. For RNA extraction, the following buffer was used: $200 \mathrm{mM}$ Tris- $\mathrm{HCl}, \mathrm{pH} 8.5$, $1.5 \%$ Li dodecylsulfate, $300 \mathrm{mM} \mathrm{LiCl}, 10 \mathrm{mM}$ disodium salt EDTA, $1 \%$ sodium deoxycholate, $1 \%$ Tergitol Nonidet ${ }^{\circledR}$ (Shell Chemicals, The Hague, The Netherlands) P-40 (NP40) and, just before use, $5 \mathrm{mM}$ thiourea, $1 \mathrm{mM}$ aurintricarboxylic acid, $10 \mathrm{mM}$ dithiothreitol, and $2 \%$ polyvinylpyrrolidone were added. Plant tissue $(200 \mathrm{mg}$ ) was ground in liquid nitrogen and the resulting powder was vigorously shaken with the $1.5 \mathrm{~mL}$ extraction buffer. The suspension was snap-frozen in liquid nitrogen. After thawing on ice, the extract was centrifuged at $8000 \times g$ for $60 \mathrm{~min}$ at $4{ }^{\circ} \mathrm{C}$. Then $40 \mu \mathrm{L}$ of $3.3 \mathrm{M}$ sodium acetate $(\mathrm{pH}$ 6.1) and $100 \mu \mathrm{L} 100 \%$ ethanol were added to the supernatant, and the mixture was chilled on ice for $10 \mathrm{~min}$ to. Polysaccharides were pelleted by centrifugation at $8000 \times \mathrm{g}$ for $30 \mathrm{~min}$ at $4{ }^{\circ} \mathrm{C}$. In order to precipitate nucleic acids $100 \mu \mathrm{L}$ of $3.3 \mathrm{M}$ sodium acetate was added and bring to a full test tube by ice-cold isopropanol, and the suspension was left at $-20{ }^{\circ} \mathrm{C}$ for $24 \mathrm{~h}$. Nucleic acid were pelleted by centrifugation for $60 \mathrm{~min}$ at $3000 \times g$ at $4{ }^{\circ} \mathrm{C}$, resuspended in $600 \mu \mathrm{L}$ of TE (10 mM Tris-HCl, pH 8.0, $1 \mathrm{mM}$ EDTA) and $600 \mu \mathrm{L} 5 \mathrm{M} \mathrm{NaCl}$ and kept on ice for $30 \mathrm{~min}$ with periodic vortex mixing. Then the samples were mixed with $300 \mu \mathrm{L}$ of $10 \%$ cetyltrimethylammonium bromide at room temperature and incubated for $5 \mathrm{~min}$ at $65^{\circ} \mathrm{C}$ to remove residual polysaccharides. Mixtures were extracted with an equal volume of chloroform/isoamylalcohol $(24: 1, v / v)$, bring to a full test tube by $10 \mathrm{M} \mathrm{LiCl}$, mixed, and kept at $4{ }^{\circ} \mathrm{C}$ overnight. RNA was pelleted by centrifugation at $16,000 \times \mathrm{g}$ for $60 \mathrm{~min}$ at $4{ }^{\circ} \mathrm{C}$, the pellet was washed in $100 \%$ ethanol, dried and dissolved in $20 \mu \mathrm{L}$ TE buffer on ice.

\subsection{DNA Constructs}

\subsubsection{Cloning Receptor cDNA}

Synthesis of cDNA was performed with 250 ng total RNA, M-MLV Reverse Transcriptase Kit (Fermentas, Canada) and oligo (dT) 21 primer according to manufacturer's instructions. The sequences of receptor sensory modules were amplified by means of Phusion High-Fidelity DNA Polymerase (Thermo Scientific, Waltham, MA, USA) and were cloning into plasmid pJET1.2 using CloneJET PCR Cloning Kit (Thermo Scientific).

All cloning was carried out using the GATEWAY ${ }^{\mathrm{TM}}$ system following the manufacturer's protocols. The cDNAs of PpCHK1-3 were obtained $[19,21]$. For obtaining entry vectors, DNA sequences encoding sensory modules with adjacent transmembrane helices (SMs + TMs) from CHK genes P $p C H K 3$, PaCHK1 and PaCHK2 were amplified using the respective primer pairs (Table S1). DNA sequences of SMs + TMs of putative receptors PpCHK4, SmCHK4a and SmCHK6 were synthesized by Evrogen (Moscow, Russia) and amplified in a two-step PCR (for primers see Table S1). The coding sequence was transferred via in vitro recombination to the destination vectors pK7WGF2 and pB7FWG2 as indicated in the text; in these constructs the GFP reporter gene was fused to CHK gene at its $5^{\prime}$ or $3^{\prime}$-terminus, respectively.

\subsubsection{Receptors Expression and CK Binding Assay}

pK7WGF2 and pB7FWG2 constructs were transformed to Agrobacterium tumefaciens strain GV3101 and transiently expressed in Nicotiana benthamiana leaves. Isolation of leaf microsomes and their use for $\mathrm{CK}$ binding determination in radioligand assays with ${ }^{3} \mathrm{H}-\mathrm{iP}$ [87] were accomplished as described earlier [14]. Transient expression was assessed by means of immunoblotting of microsomal membranes with antibodies against GFP (Agrisera, AS15 2987) diluted 1:5000 as described in [15]. Background binding of ${ }^{3} \mathrm{H}-\mathrm{iP}$ by endogenous $\mathrm{CK}$ receptors of $\mathrm{N}$. benthamiana was assessed in control probes using microsomes from untreated leaves (Figure 2). The difference between TB and NS, in other words, iP specific binding in control probes was negligible and statistically insignificant, its share in the mea- 
sured specific binding being no more than $0.7-3.6 \%$. This insignificant endogenous binding cannot alter in any way the observed ligand-binding properties of the receptors under study. A one-way ANOVA was used to compare the values (TB and NS for each receptor) resulting from the $\mathrm{CK}$ binding experiments. For all functional receptors, data on statistically extremely significant hormone specific binding $(p$-value $\leq 0.001)$ were obtained.

$K_{\mathrm{D}}$ for receptor interaction with various $C$ Ks was determined in competition experiments as described [88] according to Cheng-Prusoff calculation method [65]. The competition curves were generated using the simple ligand binding option of the SigmaPlot 12 program (Systat Software, San Jose, CA, USA). The goodness of fit for the non-linear regression model was estimated using the parameter $R$-squared $\left(R^{2}\right)$ which is a statistical measure of how close the data are to the fitted regression line. The $R^{2}$ values for all tested CHKs were close to maximum value of 1.0. An alternative method for $K_{\mathrm{D}}$ calculation from competition binding assays was given in the Appendix A and used to perform independent determination of $K_{\mathrm{D}}$ 's (Table S2).

Supplementary Materials: The following are available online at https:/ /www.mdpi.com/article/ $10.3390 /$ ijms222313077/s1.

Author Contributions: Conceptualization, S.N.L., G.A.R. and A.H.; methodology, S.N.L., P.P.P., Y.A.M., E.M.S. and D.V.A.; formal analysis, S.N.L., E.M.S. and Y.A.M.; investigation, P.P.P. (plant growing), P.P.P. and Y.A.M. (RNA isolation and cDNA synthesis), E.M.S. (receptor expression and binding assays), S.N.L., Y.A.M., A.H. (vectors design and cloning), D.V.A. (molecular modeling) and S.N.L. (bioinformatics and phylogeny); resources, S.N.L.; data curation, S.N.L. and E.M.S.; writingoriginal draft preparation, S.N.L.; writing—review and editing, G.A.R. and A.H.; funding acquisition, S.N.L. and G.A.R. All authors have read and agreed to the published version of the manuscript.

Funding: This research was funded by Russian Foundation of Basic Research, grant numbers 19-0401106 and 20-04-00797.

Institutional Review Board Statement: Not applicable.

Informed Consent Statement: Not applicable.

Data Availability Statement: Not applicable.

Conflicts of Interest: The authors declare no conflict of interest.

\section{Appendix A. A New Approach for KD Determination in Competition Experiments}

In competition experiments on ligand binding to receptors, a binding curve of the labeled ligand is plotted in the presence of increasing concentrations of unlabeled ligands. In the standard approach, the apparent dissociation constants of the receptor and unlabeled ligands are calculated using the Cheng-Prusoff equation. This formula is derived from the expression for the saturation binding curve. It is important that this expression is valid only under the condition of high superiority in concentration of the ligand over the receptor. In this case, the initial equations are simplified up to the final expression. This leads to certain limitations in the design of the experiment, often making the technique costly and inconvenient to use. By contrast, the calculation methods based on the equation for the equilibrium dissociation constant are free from such restrictions.

The formulas for the dissociation constant of labeled and unlabeled hormones in competition experiments are as follows:

$$
K_{\mathrm{D}_{\mathrm{M}}}=\frac{L_{\mathrm{M}} * R}{L R_{M}} ; K_{\mathrm{D}}=\frac{L * R}{L R}
$$

Here $L_{\mathrm{M}}$ is the concentration of unbound labeled ligand, $L R_{M}$ is the concentration of bound labeled ligand, $L$ is the concentration of unbound unlabeled ligand, $L R$ is the concentration of bound unlabeled ligand, $R$ is the concentration of free receptor. In turn, $R$, $L_{\mathrm{M}}$ and $L$ can be expressed as follows:

$$
R=R_{T}-L R_{M}-L R ; L_{M}=L_{T M}-L R_{M} ; L=L_{T}-L R
$$


Here $R_{T}, L_{T M}, L_{T}$ are the total concentrations of the receptor, labeled and unlabeled ligands prior to the initiation of the binding process. In a competition experiment, the three quantities are constants: $K_{\mathrm{DM}}, L_{T M}$ and $R_{T}$. The first value is calculated in a separate saturation binding assay. The second is initially set by the researcher. The third value, knowing the two previous ones, can be calculated from the binding of the labeled ligand in the absence of an unlabeled ligand using the following equation obtained from Equations (A1) and (A2):

$$
R_{T}(\text { constant })=\frac{K_{\mathrm{D}_{\mathrm{M}}} * L R_{M}^{L_{T}=0}}{L_{T M}-L R_{M}^{L_{T}=0}}+L R_{M}^{L_{T}=0}
$$

In the presence of an unlabeled ligand, taking into account Equations (A1) and (A2), we obtain the following equation for $K_{\mathrm{D}_{\mathrm{M}}}$ :

$$
K_{D_{M}}=\frac{\left(L_{T M}-L R_{M}\right) *\left(R_{T}-L R_{M}-L R\right)}{L R_{M}}
$$

Hence, the concentration of the bound unlabeled ligand can be expressed as:

$$
L R=\frac{K_{D_{M}} * L R_{M}}{L R_{M}-L_{T M}}-L R_{M}+R_{T}
$$

Accordingly, taking into account Equations (A1) and (A2), $K_{\mathrm{D}}$ for an unlabeled ligand can be calculated using the equation:

$$
K_{\mathrm{D}}=\frac{\left(L_{T}-L R\right) *\left(R_{T}-L R_{M}-L R\right)}{L R}
$$

$R_{T}$ and $L R$ are defined in Equations (A3) and (A5), respectively. For greater accuracy, we calculated $K_{\mathrm{D}}$ at several $L_{T} \mathrm{~s}$ and determined its average value. Results are shown in Table S2. Comparison of $K_{\mathrm{D}}$ values determined by two different calculation algorithms and displayed in Tables 1 and S2 demonstrates reasonable consistency between these two datasets.

\section{References}

1. Heyl, A.; Riefler, M.; Romanov, G.A.; Schmülling, T. Properties, functions and evolution of cytokinin receptors. Eur. J. Cell. Biol. 2012, 91, 246-256. [CrossRef]

2. Lomin, S.N.; Krivosheev, D.M.; Steklov, M.Y.; Osolodkin, D.I.; Romanov, G.A. Receptor properties and features of cytokinin signaling. Acta Nat. 2012, 4, 31-45. [CrossRef]

3. Kieber, J.J.; Schaller, G.E. Cytokinin signaling in plant development. Development 2018, 145, dev149344. [CrossRef] [PubMed]

4. Yonekura-Sakakibara, K.; Kojima, M.; Yamaya, T.; Sakakibara, H. Molecular characterization of cytokinin-responsive histidine kinases in maize. Differential ligand preferences and response to cis-zeatin. Plant Physiol. 2004, 134, 1654-1661. [CrossRef]

5. Lomin, S.N.; Yonekura-Sakakibara, K.; Romanov, G.A.; Sakakibara, H. Ligand-binding properties and subcellular localization of maize cytokinin receptors. J. Exp. Bot. 2011, 62, 5149-5159. [CrossRef]

6. Lomin, S.N.; Krivosheev, D.M.; Steklov, M.Y.; Arkhipov, D.V.; Osolodkin, D.I.; Schmülling, T.; Romanov, G.A. Plant membrane assays with cytokinin receptors underpin the unique role of free cytokinin bases as biologically active ligands. J. Exp. Bot. 2015, 66, 1851-1863. [CrossRef] [PubMed]

7. Muszynski, M.G.; Moss-Taylor, L.; Chudalayandi, S.; Cahill, J.; Del Valle-Echevarria, A.R.; Alvarez-Castro, I.; Petefish, A.; Sakakibara, H.; Krivosheev, D.M.; Lomin, S.N.; et al. The maize Hairy Sheath Frayed1 (Hsf1) mutation alters leaf patterning through increased cytokinin signaling. Plant Cell 2020, 32, 1501-1518. [CrossRef] [PubMed]

8. Choi, J.; Lee, J.; Kim, K.; Cho, M.; Ryu, H.; An, G.; Hwang, I. Functional identification of OsHk6 as a homotypic cytokinin receptor in rice with preferential affinity for iP. Plant Cell Physiol. 2012, 53, 1334-1343. [CrossRef]

9. Ding, W.; Tong, H.; Zheng, W.; Ye, J.; Pan, Z.; Zhang, B.; Zhu, S. Isolation, characterization and transcriptome analysis of a cytokinin receptor mutant Osckt1 in rice. Front. Plant. Sci. 2017, 8, 88. [CrossRef]

10. Laffont, C.; Rey, T.; André, O.; Novero, M.; Kazmierczak, T.; Debellé, F.; Bonfante, P.; Jacquet, C.; Frugier, F. The CRE1 cytokinin pathway is differentially recruited depending on Medicago truncatula root environments and negatively regulates resistance to a pathogen. PLoS ONE 2015, 10, e0116819. [CrossRef]

11. Boivin, S.; Kazmierczak, T.; Brault, M.; Wen, J.; Gamas, P.; Mysore, K.S.; Frugier, F. Different cytokinin histidine kinase receptors regulate nodule initiation as well as later nodule developmental stages in Medicago truncatula. Plant Cell Environ. 2016, 39, 2198-2209. [CrossRef] 
12. Kuderová, A.; Gallová, L.; Kuricová, K.; Nejedlá, E.; Čurdová, A.; Micenková, L.; Plíhal, O.; Šmajs, D.; Spíchal, L.; Hejátko, J. Identification of AHK2- and AHK3-like cytokinin receptors in Brassica napus reveals two subfamilies of AHK2 orthologues. J. Exp. Bot. 2015, 66, 339-353. [CrossRef]

13. Daudu, D.; Allion, E.; Liesecke, F.; Papon, N.; Courdavault, V.; Dugé de Bernonville, T.; Mélin, C.; Oudin, A.; Clastre, M.; Lanoue, A.; et al. CHASE-Containing histidine kinase receptors in apple tree: From a common receptor structure to divergent cytokinin binding properties and specific functions. Front. Plant. Sci. 2017, 8, 1614. [CrossRef]

14. Lomin, S.N.; Myakushina, Y.A.; Kolachevskaya, O.O.; Getman, I.A.; Arkhipov, D.V.; Savelieva, E.M.; Osolodkin, D.I.; Romanov, G.A. Cytokinin perception in potato: New features of canonical players. J. Exp. Bot. 2018, 69, 3839-3853. [CrossRef]

15. Lomin, S.N.; Savelieva, E.M.; Arkhipov, D.V.; Romanov, G.A. Evidences for preferential localization of cytokinin receptors of potato in the endoplasmic reticulum. Biochem. Moscow Suppl. Ser. A Membrane Cell Biol. 2020, 14, 146-153. [CrossRef]

16. Jaworek, P.; Tarkowski, P.; Hluska, T.; Kouřil, Š.; Vrobel, O.; Nisler, J.; Kopečny, D. Characterization of five CHASE-containing histidine kinase receptors from Populus x canadensis cv. Robusta sensing isoprenoid and aromatic cytokinins. Planta 2020, 251, 1. [CrossRef]

17. Héricourt, F.; Larcher, M.; Chefdor, F.; Koudounas, K.; Carqueijeiro, I.; Cruz, P.L.; Courdavault, V.; Tanigawa, M.; Maeda, T.; Depierreux, C.; et al. New insight into HPts as hubs in poplar cytokinin and osmosensing multistep phosphorelays: Cytokinin pathway uses specific HPts. Plants 2019, 8, 591. [CrossRef] [PubMed]

18. von Schwartzenberg, K.; Núñez, M.F.; Blaschke, H.; Dobrev, P.I.; Novák, O.; Motyka, V.; Strnad, M. Cytokinins in the bryophyte Physcomitrella patens: Analyses of activity, distribution, and cytokinin oxidase/dehydrogenase overexpression reveal the role of extracellular cytokinins. Plant Physiol. 2007, 145, 786-800. [CrossRef] [PubMed]

19. von Schwartzenberg, K.; Lindner, A.C.; Gruhn, N.; Šimura, J.; Novák, O.; Strnad, M.; Gonneau, M.; Nogué, F.; Heyl, A. CHASE domain-containing receptors play an essential role in the cytokinin response of the moss Physcomitrella patens. J. Exp. Bot. 2016, 67, 667-679. [CrossRef]

20. Kaltenegger, E.; Leng, S.; Heyl, A. The effects of repeated whole genome duplication events on the evolution of cytokinin signaling pathway. BMC Evol. Biol. 2018, 18, 76. [CrossRef]

21. Gruhn, N.; Halawa, M.; Snel, B.; Seidl, M.F.; Heyl, A. A subfamily of putative cytokinin receptors is revealed by an analysis of the evolution of the two-component signaling system of plants. Plant Physiol. 2014, 165, 227-237. [CrossRef] [PubMed]

22. Aki, S.S.; Mikami, T.; Naramoto, S.; Nishihama, R.; Ishizaki, K.; Kojima, M.; Takebayashi, Y.; Sakakibara, H.; Kyozuka, J.; Kohchi, T.; et al. Cytokinin signaling is essential for organ formation in Marchantia polymorpha. Plant Cell Physiol. 2019, 60, 1842-1854. [CrossRef] [PubMed]

23. Kakimoto, T. Perception and signal transduction of cytokinins. Annu. Rev. Plant Biol. 2003, 54, 605-627. [CrossRef] [PubMed]

24. Heyl, A.; Schmülling, T. Cytokinin signal perception and transduction. Curr. Opin. Plant. Biol. 2003, 6, 480-488. [CrossRef]

25. Sakakibara, H. Cytokinins: Activity, biosynthesis, and translocation. Annu. Rev. Plant Biol. 2006, 57, 431-449. [CrossRef] [PubMed]

26. Kieber, J.J.; Schaller, G.E. Cytokinins. Arab. Book 2014, 12, e0168. [CrossRef]

27. Spíchal, L.; Rakova, N.Y.; Riefler, M.; Mizuno, T.; Romanov, G.A.; Strnad, M.; Schmülling, T. Two cytokinin receptors of Arabidopsis thaliana, CRE1/AHK4 and AHK3, differ in their ligand specificity in a bacterial assay. Plant Cell Physiol. 2004, 45, 1299-1305. [CrossRef]

28. Romanov, G.A.; Lomin, S.N.; Schmülling, T. Biochemical characteristics and ligand-properties of Arabidopsis cytokinin receptor AHK3 compared to CRE1/AHK4 as revealed by a direct binding assay. J. Exp. Bot. 2006, 57, 4051-4058. [CrossRef]

29. Riefler, M.; Novak, O.; Strnad, M.; Schmülling, T. Arabidopsis cytokinin receptor mutants reveal functions in shoot growth, leaf senescence, seed size, germination, root development, and cytokinin metabolism. Plant Cell 2006, 18, 40-54. [CrossRef] [PubMed]

30. Mähönen, A.P.; Higuchi, M.; Törmäkangas, K.; Miyawaki, K.; Pischke, M.S.; Sussman, M.R.; Helariutta, Y.; Kakimoto, T. Cytokinins regulate a bidirectional phosphorelay network in Arabidopsis. Curr. Biol. 2006, 16, 1116-1122. [CrossRef]

31. Romanov, G.A. How do cytokinins affect the cell? Russ. J. Plant. Physiol. 2009, 56, 268-290. [CrossRef]

32. Stolz, A.; Riefler, M.; Lomin, S.N.; Achazi, K.; Romanov, G.A.; Schmülling, T. The specificity of cytokinin signalling in Arabidopsis thaliana is mediated by differing ligand affinities and expression profiles of the receptors. Plant J. 2011, 67, 157-168. [CrossRef]

33. Hothorn, M.; Dabi, T.; Chory, J. Structural basis for cytokinin recognition by Arabidopsis thaliana histidine kinase AHK4. Nat. Chem. Biol. 2011, 7, 766-768. [CrossRef] [PubMed]

34. Ueguchi, C.; Sato, S.; Kato, T.; Tabata, S. The AHK4 gene involved in the cytokinin-signaling pathway as a direct receptor molecule in Arabidopsis thaliana. Plant Cell Physiol. 2001, 42, 751-755. [CrossRef] [PubMed]

35. Higuchi, M.; Pischke, M.S.; Mähönen, A.P.; Miyawaki, K.; Hashimoto, Y.; Seki, M.; Kobayashi, M.; Shinozaki, K.; Kato, T.; Tabata, S.; et al. In planta functions of the Arabidopsis cytokinin receptor family. Proc. Natl. Acad. Sci. USA 2004, 101, 8821-8826. [CrossRef] [PubMed]

36. Matsumoto-Kitano, M.; Kusumoto, T.; Tarkowski, P.; Kinoshita-Tsujimura, K.; Václavíková, K.; Miyawaki, K.; Kakimoto, T. Cytokinins are central regulators of cambial activity. Proc. Natl. Acad. Sci. USA 2008, 105, 20027-20031. [CrossRef] [PubMed]

37. Hirose, N.; Takei, K.; Kuroha, T.; Kamada-Nobusada, T.; Hayashi, H.; Sakakibara, H. Regulation of cytokinin biosynthesis, compartmentalization and translocation. J. Exp. Bot. 2008, 59, 75-83. [CrossRef] [PubMed]

38. Takei, K.; Yamaya, T.; Sakakibara, H. Arabidopsis CYP735A1 and CYP735A2 encode cytokinin hydroxylases that catalyze the biosynthesis of trans-Zeatin. J. Biol. Chem. 2004, 279, 41866-41872. [CrossRef] 
39. Kiba, T.; Takei, K.; Kojima, M.; Sakakibara, H. Side-chain modification of cytokinins controls shoot growth in Arabidopsis. Dev. Cell. 2013, 27, 452-461. [CrossRef] [PubMed]

40. Werner, S.; Bartrina, I.; Schmülling, T. Cytokinin regulates vegetative phase change in Arabidopsis thaliana through the miR172/TOE1-TOE2 module. Nat. Commun. 2021, 12, 5816. [CrossRef]

41. Bishopp, A.; Help, H.; El-Showk, S.; Weijers, D.; Scheres, B.; Friml, J.; Benková, E.; Mähönen, A.P.; Helariutta, Y. A mutually inhibitory interaction between auxin and cytokinin specifies vascular pattern in roots. Curr. Biol. 2011, 21, 917-926. [CrossRef]

42. Wang, C.; Liu, Y.; Li, S.S.; Han, G.Z. Insights into the origin and evolution of the plant hormone signaling machinery. Plant. Physiol. 2015, 167, 872-886. [CrossRef] [PubMed]

43. Lindner, A.C.; Lang, D.; Seifert, M.; Podlešáková, K.; Novák, O.; Strnad, M.; Reski, R.; von Schwartzenberg, K. Isopentenyltransferase-1 (IPT1) knockout in Physcomitrella together with phylogenetic analyses of IPTs provide insights into evolution of plant cytokinin biosynthesis. J. Exp. Bot. 2014, 65, 2533-2543. [CrossRef]

44. Sanders, H.L.; Langdale, J.A. Conserved transport mechanisms but distinct auxin responses govern shoot patterning in Selaginella kraussiana. New Phytol. 2013, 198, 419-428. [CrossRef] [PubMed]

45. de Vries, J.; Fischer, A.M.; Roettger, M.; Rommel, S.; Schluepmann, H.; Bräutigam, A.; Carlsbecker, A.; Gould, S.B. Cytokinininduced promotion of root meristem size in the fern Azolla supports a shoot-like origin of euphyllophyte roots. New Phytol. 2016, 209, 705-720. [CrossRef]

46. Valdés, A.E.; Fernández, B.; Centeno, M.L. Alterations in endogenous levels of cytokinins following grafting of Pinus radiata support ratio of cytokinins as an index of ageing and vigour. J. Plant. Physiol. 2003, 160, 1407-1410. [CrossRef]

47. Zhang, H.; Horgan, K.J.; Stewart Reynolds, P.H.; Norris, G.E.; Jameson, P.E. Novel cytokinins: The predominant forms in mature buds of Pinus radiata. Physiol. Plant. 2001, 112, 127-134. [CrossRef]

48. Montalbán, I.A.; De Diego, N.; Moncaleán, P. Testing novel cytokinins for improved in vitro adventitious shoots formation and subsequent ex vitro performance in Pinus radiata. Forestry 2011, 84, 363-373. [CrossRef]

49. Strnad, M. The aromatic cytokinins. Physiol. Plant 1997, 101, 674-688. [CrossRef]

50. Nieminen, K.; Immanen, J.; Laxell, M.; Kauppinen, L.; Tarkowski, P.; Dolezal, K.; Tähtiharju, S.; Elo, A.; Decourteix, M.; Ljung, K.; et al. Cytokinin signaling regulates cambial development in poplar. Proc. Natl. Acad. Sci. USA 2008, 105, $20032-20037$. [CrossRef] [PubMed]

51. De Diego, N.; Montalbán, I.A.; Moncaleán, P. In Vitro regeneration of adult Pinus sylvestris L. trees. S. Afr. J. Bot. 2010, 76, 158-162. [CrossRef]

52. Pullman, G.S.; Bucalo, K. Pine somatic embryogenesis using zygotic embryos as explants. Methods Mol. Biol. 2011, 710, 267-291. [CrossRef]

53. Uggla, C.; Mellerowicz, E.J.; Sundberg, B. Indole-3-acetic acid controls cambial growth in scots pine by positional signaling. Plant Physiol. 1998, 117, 113-121. [CrossRef]

54. Uggla, C.; Magel, E.; Moritz, T.; Sundberg, B. Function and dynamics of auxin and carbohydrates during earlywood/latewood transition in scots pine. Plant Physiol 2001, 125, 2029-2039. [CrossRef]

55. Hejnowicz, A.; Tomaszewski, M. Growth regulators and wood formation in Pinus silvestris. Physiol. Plant. 1969, $22,984-992$. [CrossRef]

56. Carvalho, A.; Paiva, J.; Louzada, J.; Lima-Brito, J. The transcriptomics of secondary growth and wood formation in conifers. Mol. Biol. Int. 2013, 2013, 974324. [CrossRef] [PubMed]

57. Hartmann, F.P.; Rathgeber, C.B.K.; Badel, É.; Fournier, M.; Moulia, B. Modelling the spatial crosstalk between two biochemical signals explains wood formation dynamics and tree-ring structure. J. Exp. Bot. 2021, 72, 1727-1737. [CrossRef]

58. Steklov, M.Y.; Lomin, S.N.; Osolodkin, D.I.; Romanov, G.A. Structural basis for cytokinin receptor signaling: An evolutionary approach. Plant. Cell. Rep. 2013, 32, 781-793. [CrossRef] [PubMed]

59. Lomin, S.N.; Myakushina, Y.A.; Arkhipov, D.V.; Leonova, O.G.; Popenko, V.I.; Schmülling, T.; Romanov, G.A. Studies of cytokinin receptor-phosphotransmitter interaction provide evidences for the initiation of cytokinin signalling in the endoplasmic reticulum. Funct. Plant. Biol. 2018, 45, 192-202. [CrossRef]

60. Anantharaman, V.; Aravind, L. The CHASE domain: A predicted ligand-binding module in plant cytokinin receptors and other eukaryotic and bacterial receptors. Trends. Biochem. Sci. 2001, 26, 579-582. [CrossRef]

61. Mougel, C.; Zhulin, I.B. CHASE: An extracellular sensing domain common to transmembrane receptors from prokaryotes, lower eukaryotes and plants. Trends. Biochem. Sci. 2001, 26, 582-584. [CrossRef]

62. Heyl, A.; Brault, M.; Frugier, F.; Kuderova, A.; Lindner, A.C.; Motyka, V.; Rashotte, A.M.; von Schwartzenberg, K.; Vankova, R.; Schaller, G.E. Nomenclature for members of the two-component signaling pathway of plants. Plant. Physiol. 2013, 161, $1063-1065$. [CrossRef] [PubMed]

63. Pils, B.; Heyl, A. Unraveling the evolution of cytokinin signaling. Plant. Physiol. 2009, 151, 782-791. [CrossRef]

64. Gruhn, N.; Seidl, M.F.; Halawa, M.; Heyl, A. Members of a recently discovered subfamily of cytokinin receptors display differences and similarities to their classical counterparts. Plant. Signal. Behav. 2015, 10, 2. [CrossRef] [PubMed]

65. Cheng, Y.C.; Prusoff, W.H. Relationship between the inhibition constant (KI) and the concentration of inhibitor which causes 50 per cent inhibition (I50) of an enzymatic reaction. Biochem. Pharmacol. 1973, 22, 3099-3108. [CrossRef]

66. Spíchal, L. Cytokinins-Recent news and views of evolutionally old molecules. Func. Plant Biol. 2012, 39, 267-284. [CrossRef] 
67. Morris, J.L.; Puttick, M.N.; Clark, J.W.; Edwards, D.; Kenrick, P.; Pressel, S.; Wellman, C.H.; Yang, Z.; Schneider, H.; Donoghue, P.C.J. The timescale of early land plant evolution. Proc. Natl. Acad. Sci. USA 2018, 115, E2274-E2283. [CrossRef]

68. Felle, H.H. pH regulation in anoxic plants. Ann. Bot. 2005, 96, 519-532. [CrossRef]

69. Sweeney, E.G.; Henderson, J.N.; Goers, J.; Wreden, C.; Hicks, K.G.; Foster, J.K.; Parthasarathy, R.; Remington, S.J.; Guillemin, K. Structure and proposed mechanism for the $\mathrm{pH}$-sensing Helicobacter pylori chemoreceptor TlpB. Structure 2012, 20, 1177-1188. [CrossRef]

70. Dortay, H.; Mehnert, N.; Bürkle, L.; Schmülling, T.; Heyl, A. Analysis of protein interactions within the cytokinin-signaling pathway of Arabidopsis thaliana. FEBS J. 2006, 273, 4631-4644. [CrossRef]

71. Caesar, K.; Thamm, A.M.; Witthöft, J.; Elgass, K.; Huppenberger, P.; Grefen, C.; Horak, J.; Harter, K. Evidence for the localization of the Arabidopsis cytokinin receptors AHK3 and AHK4 in the endoplasmic reticulum. J. Exp. Bot. 2011, 62, 5571-5580. [CrossRef] [PubMed]

72. Gordon, S.P.; Chickarmane, V.S.; Ohno, C.; Meyerowitz, E.M. Multiple feedback loops through cytokinin signaling control stem cell number within the Arabidopsis shoot meristems. Proc. Nat. Acad. Sci. USA 2009, 160, 16529-16534. [CrossRef] [PubMed]

73. Schaller, G.E.; Street, I.H.; Kieber, J.J. Cytokinin and the cell cycle. Curr. Opin. Plant. Biol. 2014, 21, 7-15. [CrossRef] [PubMed]

74. Kolachevskaya, O.O.; Myakushina, Y.A.; Getman, I.A.; Lomin, S.N.; Deyneko, I.V.; Deigraf, S.V.; Romanov, G.A. Hormonal regulation and crosstalk of auxin/cytokinin signaling pathways in potatoes in vitro and in relation to vegetation or tuberization stages. Int. J. Mol. Sci. 2021, 22, 8207. [CrossRef] [PubMed]

75. Zdarska, M.; Cuyacot, A.R.; Tarr, P.T.; Yamoune, A.; Szmitkowska, A.; Hrdinová, V.; Gelová, Z.; Meyerowitz, E.M.; Hejátko, J. ETR1 integrates response to ethylene and cytokinins into a single multistep phosphorelay pathway to control root growth. Mol. Plant. 2019, 12, 1338-1352. [CrossRef]

76. Tamura, K.; Stecher, G.; Peterson, D.; Filipski, A.; Kumar, S. MEGA6: Molecular Evolutionary Genetics Analysis version 6.0. Mol. Biol. Evol. 2013, 30, 2725-2729. [CrossRef]

77. Tamura, K.; Stecher, G.; Kumar, S. MEGA 11: Molecular Evolutionary Genetics Analysis Version 11. Mol. Biol. Evol. 2021, 38, 3022-3027. [CrossRef] [PubMed]

78. Tajima, F.; Nei, M. Estimation of evolutionary distance between nucleotide sequences. Mol. Biol. Evol. 1984, 1, 269-285. [CrossRef] [PubMed]

79. Hu, B.; Jin, J.; Guo, A.Y.; Zhang, H.; Luo, J.; Gao, G. GSDS 2.0: An upgraded gene feature visualization server. Bioinformatics 2015, 31, 1296-1297. [CrossRef] [PubMed]

80. Webb, B.; Sali, A. Comparative protein structure modeling using MODELLER. Curr. Protoc. Bioinform. 2014, 47, 5.6.1-5.6.32. [CrossRef]

81. Shen, M.Y.; Sali, A. Statistical potential for assessment and prediction of protein structures. Protein Sci. 2006, 15, $2507-2524$. [CrossRef]

82. McGuffin, L.J.; Adiyaman, R.; Maghrabi, A.H.A.; Shuid, A.N.; Brackenridge, D.A.; Nealon, J.O.; Philomina, L.S. IntFOLD: An integrated web resource for high performance protein structure and function prediction. Nucleic Acids Res. 2019, 47, W408-W413. [CrossRef] [PubMed]

83. Pettersen, E.F.; Goddard, T.D.; Huang, C.C.; Couch, G.S.; Greenblatt, D.M.; Meng, E.C.; Ferrin, T.E. UCSF Chimera-A visualization system for exploratory research and analysis. J. Comput. Chem. 2004, 25, 1605-1612. [CrossRef] [PubMed]

84. Maier, J.A.; Martinez, C.; Kasavajhala, K.; Wickstrom, L.; Hauser, K.E.; Simmerling, C. ff14SB: Improving the Accuracy of Protein Side Chain and Backbone Parameters from ff99SB. J. Chem. Comput. 2015, 11, 3696-3713. [CrossRef]

85. Kolosova, N.; Miller, B.; Ralph, S.; Ellis, B.E.; Douglas, C.; Ritland, K.; Bohlmann, J. Isolation of high-quality RNA from gymnosperm and angiosperm trees. Nat. Rev. Genet. 2004, 2, 353-359. [CrossRef] [PubMed]

86. Pashkovskiy, P.P.; Vankova, R.; Zlobin, I.E.; Dobrev, P.; Ivanov, Y.V.; Kartashov, A.V.; Kuznetsov, V.V. Comparative analysis of abscisic acid levels and expression of abscisic acid-related genes in Scots pine and Norway spruce seedlings under water deficit. Plant Physiol. Biochem. 2019, 140, 105-112. [CrossRef] [PubMed]

87. Sidorov, G.V.; Myasoedov, N.F.; Lomin, S.N.; Romanov, G.A. Synthesis of tritium- and deuterium-labeled isopentenyladenine. Radiochemistry 2015, 57, 108-110. [CrossRef]

88. Romanov, G.A.; Lomin, S.N. Hormone-binding assay using living bacteria expressing eukaryotic receptors. Methods Mol. Biol. 2009, 495, 111-120. [CrossRef] [PubMed] 